\title{
PERBAIKAN PROFIL LIPID PADA PEREMPUAN DEWASA KELEBIHAN BERAT BADAN SETELAH INTERVENSI SARI JERUK KALAMANSI (Citrus microcarpa)
}

\section{(Intervention of calamansi juice [Citrus microcarpa] to improve lipid profile of overweight adult women)}

\author{
Sutemy Surlitah $^{1 *}$, Budi Setiawan ${ }^{1}$, Dodik Briawan ${ }^{1}$ \\ ${ }^{1}$ Departemen Gizi Masyarakat, Fakultas Ekologi Manusia (FEMA), Institut Pertanian Bogor, Bogor 16680
}

\begin{abstract}
The objective of this research was to analyze the effect of calamansi juice intervention on lipid profiles of overweight adult women. The pre-post and randomized single-blinded clinical study were applied on 24 subjects who were randomly and alocated into two group, i.e group A (300 ml 100\% pure calamansi juice) and group B (300 $\mathrm{ml}$ and $50 \%$ concentrante calamansi juice). The juice was given twice a day (each $150 \mathrm{ml}$ ) for 28 days and lipid profiles were analyzed before and after intervention. The result showed a significant decrease $(p<0.05)$ after intervention in Triglyseride plasma $(T G)$ level $(-23.67 \pm 21.81$ and $-2.33 \pm 22.39 \mathrm{mg} / \mathrm{dl})$, low density lipoprotein ( $L D L-c)-30.58 \pm 25.05$ and $12.42 \pm 26.66$ $\mathrm{mg} / \mathrm{d}$ ), total cholesterol (TC) $23.50 \pm 30.90$ and $12.00 \pm 30.80 \mathrm{mg} / \mathrm{dl}$ and a significant increase $(p<0.05)$ in high density lipoprotein (HDL-c) plasma level (10.25 11.91 and $0.33 \pm 8.57 \mathrm{mg} / \mathrm{dl})$. Meanwhile, in group $B$ there was no significant change in lipid profiles. The intervention of $300 \mathrm{ml}$ pure calamansi juice improved the lipid profile of overweight women.
\end{abstract}

Keywords: citrus juice calamansi, lipid profile, overweight adult women

\begin{abstract}
ABSTRAK
Tujuan penelitian ini adalah menganalisis efek intervensi jeruk kalamansi terhadap profil lipid pada perempuan dewasa dengan berat badan lebih. Metode yang digunakan adalah pre-post and randomized single-blinding study yang melibatkan 24 orang subjek yang diacak kedalam dua perlakuan, yaitu perlakuan A (300 ml sari jeruk kalamansi 100\%) dan perlakuan B (300 ml konsentrat sari jeruk kalamansi 50\%). Sari jeruk kalamansi diberikan dua kali sehari (masing-masing $150 \mathrm{ml}$ ) selama 28 hari dan profil lipid dianalisis sebelum dan sesudah intervensi. Hasil penelitian menunjukkan bahwa terdapat penurunan yang signifikan $(\mathrm{p}<0,05)$ pada Trigliserida (TG) plasma $(-23,67 \pm 21,81 \mathrm{dan}-2,33 \pm 22,39 \mathrm{mg} /$ dl), Low Density Lipoprotein (LDL-c) plasma (-30,58 $\pm 25,05$ dan 12,42 $\pm 26,66 \mathrm{mg} / \mathrm{dl})$, kolesterol total (TC) plasma $(-23,50 \pm 30,90$ dan $12,00 \pm 30,80 \mathrm{mg} / \mathrm{dl})$ serta terdapat peningkatan signifikan $(\mathrm{p}<0,05)$ pada High Density Lipoprotein (HDL-c) plasma $(10,25 \pm 11,91$ dan $0,33 \pm 8,57 \mathrm{mg} / \mathrm{dl}$ ) setelah intervensi. Namun sebaliknya pada perlakuan B tidak terdapat penurunan yang signifikan sebelum dan setelah intervensi pada profil lipid. Pemberian sari jeruk kalamansi dengan kadar 100\% sebanyak $300 \mathrm{ml}$ dapat memperbaiki profil lipid pada perempuan dewasa yang kelebihan berat badan.
\end{abstract}

Kata kunci: perempuan dewasa kelebihan berat badan, profil lipid, sari jeruk kalamansi

\section{PENDAHULUAN}

World Health Organization (WHO) (2010) melaporkan bahwa proporsi kematian pada usia kurang dari 70 tahun sebanyak 30\% disebabkan oleh penyakit jantung koroner (PJK), kanker $27 \%$, dan diabetes $4 \%$. Lebih dari 2,6 juta orang meninggal dunia akibat mengalami kolesterol tinggi. Salah satu pemicu terjadinya penyakit tersebut disebabkan oleh kegemukan dan obesitas. Kegemukan dan obesitas itu sendiri dapat memicu gangguan pada kolesterol dalam darah terutama kolesterol LDL (low density lipoprotein) dan trigliserida. Menurut laporan Kementerian Kesehatan (2013), abnormalitas kadar lipid dalam darah merupakan salah satu faktor risiko

\footnotetext{
"Koresponsdensi: Telp: +6285286050801,Surel: sutemi66@gmail.com
} 
timbulnya penyakit degeneratif seperti penyakit kardiovaskular dan gangguan metabolik, misalnya aterosklerosis dan stroke.

Penyakit degeneratif telah menjadi masalah kesehatan di berbagai negara berkembang dan maju, termasuk di Indonesia. Menurut WHO (2011), sepertiga dari setengah orang dewasa di dunia memiliki kadar koleterol yang tinggi dalam darah, dan Indonesia menempati posisi ketiga di Asia Tenggara dengan persentase perempuan 39\% dan pria 35\%. Depkes RI (2013) menyatakan bahwa persentase kejadian kolesterol abnormal pada penduduk usia $\geq 15$ tahun di Indonesia secara nasional adalah $35,9 \%$, pada lakilaki sebesar $30,0 \%$, sedangkan pada perempuan lebih tinggi yakni 39,6\%. Apabila abnormalitas kolesterol dalam jangka waktu lama dibiarkan, maka akan mengakibatkan tingginya kolesterol dalam plasma darah.

Lembaga Ilmu Pengetahuan Indonesia (LIPI) (2009) dan Cooper (2000) menyatakan bahwa terdapat beberapa hal yang menyebabkan tingginya kolesterol, yakni usia, obesitas, diet tinggi lemak, konsumsi alkohol, kebiasaan merokok, diabetes, riwayat keluarga atau genetik, dan aktivitas fisik. Selanjutnya menurut Murray et al. (2014), jenis kelamin juga merupakan faktor yang menyebabkan tingginya kadar kolesterol.

Buah jeruk memiliki bahan aktif yang penting bagi kesehatan seperti vitamin $\mathrm{C}$, flavonoid, karotenoid, limonoid, dan mineral (Cano et al. 2008). Penelitian secara in vivo oleh Miyake (2006) pada tikus yang diberi diet tinggi lemak dan tinggi kolesterol memberikan hasil terjadinya penurunan lipid setelah diberikan jeruk. Hal tersebut dikarenakan flavonoid dalam buah jeruk memiliki kandungan antioksidan yang memiliki sifat antihipertensi dan antihiperkolesterolemia.

Boekholdt et al. (2006) menyatakan bahwa kandungan vitamin $\mathrm{C}$ jeruk dapat melindungi sel endotel dan LDL dari oksidan intra atau ekstraselular dan juga dapat mengurangi risiko aterosklerosis. Menurut Arabbi et al. (2004), 70\% dari total flavonoid yang dikonsumsi oleh orang Brazil disediakan oleh jeruk dan jus jeruk. Jus jeruk juga merupakan minuman yang populer di sebagian besar negara barat, dikonsumsi oleh masyarakat umum sebagai bagian dari makanan sehat dan sebagai sumber vitamin dan mineral.

Flavonoid utama dalam jeruk ialah naringin, narirutin, dan hesperidin (Jacob et al. 2000) yang terdapat pada kulit buah dan daging buah jeruk (Tripoli et al. 2007). Flavonoid merupakan bahan antioksidan yang mampu menetralisir oksigen reaktif dan berkontribusi terhadap pence- gahan penyakit kronis seperti kanker (Fergusson 2002; Paulose 2005; Tripoli et al. 2007). Kurowska et al. (2000) menyatakan bahwa senyawa flavonoid dari buah jeruk, seperti hesperidin dan naringin dapat mengurangi kolesterol LDL dan trigliserida pada hewan dan manusia, dan dapat meningkatkan kolesterol HDL pada individu hiperkolesterolemia. Flavonoid dari jus jeruk memengaruhi metabolisme kolesterol di hati (Kurowska et al. 2000), karena menghambat produksi lipoprotein endogen (Bok et al. 1999).

Kalamansi dengan nama ilmiah citrus microcarpa dan juga dikenal sebagai Limau kasturi (Malaysia), kuwquat (Philipina), kalamansi (Indonesia) merupakan spesies dari rutaceae. Wang et al. (2007) menyatakan bahwa buah kalamansi berbentuk bulat kecil, berwarna kuning kehijauan, memiliki ukuran diameter $4-5 \mathrm{~cm}$, dan memiliki rasa asam dan tekstur berserat. Kalamansi diklasifikasikan sebagai buah sitrus, meliputi lemon dan limau, memiliki daging berwarna jingga, berair, asam, dan memiliki kemiripan rasa seperti jeruk nipis. Berdasarkan penelitian Bhat et al. (2011), komponen bioaktif jeruk kalamansi (ctrus microcarpa) meliputi asam askorbat sebesar $40,20 \pm 0,5 \mathrm{mg} / 100 \mathrm{ml}$, flavonoid $1,41 \pm 1,2$ $\mathrm{mg} / 100 \mathrm{ml}$, dan aktivitas antioksidan $777,0 \pm 1,7$ $\mathrm{mg} / 100 \mathrm{ml}$.

Wang et al. (2008) mengklasifikasikan komponen bioaktif dari berbagai varian jenis jeruk (citrus) yang terdapat pada daging buah dan kulit jeruk dan didapati hasil bahwa jeruk kalamansi memiliki total polifenol sebesar $52,3 \pm 1,55 \mathrm{mg} / \mathrm{g}$, total flavonoid pada daging sebesar $8,41 \pm 0,32$ $\mathrm{mg} / \mathrm{g}$ dan kulit jeruk $41,0 \pm 1,37 \mathrm{mg} / \mathrm{g}$. Sedangkan total karotenoid pada daging sebesar $0,11 \pm 0,003$ $\mathrm{mg} / \mathrm{g}$ dan kulit jeruk sebesar $0,74 \pm 0,029 \mathrm{mg} / \mathrm{g}$.

Penelitian-penelitian tentang pengaruh jeruk terhadap perubahan profil lipid juga telah banyak dilakukan meskipun hasilnya sangat beragam. Sedangkan penelitian terkait pengaruh jeruk kalamansi terhadap profil lipid secara in vivo sejauh yang peneliti ketahui belum ada. Berdasarkan informasi terkait kandungan buah jeruk kalamansi tersebut, peneliti tertarik untuk melakukan penelitian terkait efek dari jeruk kalamansi terhadap profil lipid darah yang diujikan pada perempuan dewasa dengan berat badan lebih.

\section{METODE}

\section{Desain, tempat, dan waktu}

Penelitian ini merupakan penelitian eksperimental yang menggunakan desain prepost dengan randomized single-blinding clinical 
study. Penelitian dilakukan di Kota Bengkulu selama 28 hari (4 minggu) dan dilaksanakan pada bulan April hingga Desember 2016.

\section{Jumlah dan cara pengambilan subjek}

Subjek dalam penelitian ini adalah karyawan dan guru di sekolah Pendidikan Anak Usia Dini Auladuna Islam Terpadu (PAUD-IT Auladuna) dan masyarakat disekitar PAUD-IT Auladuna Kota Bengkulu yang memenuhi kriteria inklusi berupa perempuan berusia $\geq 30$ tahun (Simpson $e t$ al. 2012), dan overweight dengan indeks massa tubuh (IMT) $\geq 23 \mathrm{~kg} / \mathrm{m}^{2}$ (WHO 2000). Kriteria eksklusi subjek dalam penelitian ini yaitu mengalami penyakit hati, maag, ginjal, gangguan tiroid, kanker, penyakit jantung koroner (PJK), stroke, diabetes melitus dan penyakit lainnya; rutin mengonsumsi suplemen; sedang dalam terapi diet atau sedang menjalani pengobatan.

Penentuan jumlah subjek pada penelitian ini berdasarkan data jumlah subjek, rata-rata dan standar deviasi pengukuran profil lipid (Kurowska et al. 2000). Apabila $\alpha=5 \%$ dan power test $(\beta)$ sebesar $95 \%$ dan dengan estimasi drop out $10 \%$ adalah 14 orang. Dikarenakan terdapat dua perlakukan yang diberikan pada penelitian ini, yaitu perlakuan A (100\% sari jeruk kalamansi (SJK)) dan perlakuan B $(50 \%$ konsentrat sari jeruk kalamansi), maka didapatkan total jumlah subjek sebanyak 28 orang (perlakuan A diberikan pada 14 orang dan perlakuan B pada 14 orang).

Penelitian ini bersifat single blinding, yakni subjek tidak mengetahui perlakuan yang diberikan apakah perlakuan A dan perlakuan B. Subjek dikelompokkan secara acak, sehingga setiap subjek memiliki kemungkinan yang sama untuk mendapatkan perlakuan A dan perlakuan B. Penelitian ini juga telah lolos kaji etik dari komite etik penelitian kesehatan Fakultas Kedokteran Universitas Indonesia (FK-UI) dengan nomor: 830/UN2.F1/ETIK/2016.

\section{Bahan dan alat}

Bahan utama yang akan digunakan dalam penelitian ini adalah jeruk kalamansi, pemanis gula stevia (glikosida steviol), plasma darah 5 $\mathrm{ml}$, pereaksi kolesterol, pereaksi trigliserida, dan pereaksi HDL.

Alat yang digunakan adalah mesin pemeras jeruk, blender, freezer, timbangan analitik dan digital, microtoise, gelas ukur, photometer biosytem BTS 350, clinippe 1000 UI dan 10 UI, tabung reaksi, rak tabung, tips kuning dan tips biru, timer, dan waterbath.

\section{Tahapan penelitian}

Pembuatan sari jeruk kalamansi. Sari jeruk kalamansi (SJK) diperoleh dari petani jeruk kalamansi di Kota Bengkulu dan metode pembuatan SJK diperas menggunakan mesin pemeras jeruk. Buah jeruk kalamansi disortasi dan dibersihkan lalu dimasukkan kedalam mesin pemeras. SJK yang telah diperas selanjutnya disaring 1-2 jam dengan tujuan untuk memisahkan minyak atsiri dari kulit jeruk dan sari jeruk yang akan dikonsumsi.

Intervensi. Intervensi diberikan sebanyak 2 kali dalam sehari, yakni pagi (09.00 WIB) dan siang (13.00 WIB) dengan takaran setiap pemberian sebanyak $150 \mathrm{ml}$. Pengisian form pemantauan kepatuhan konsumsi dilakuan setiap hari oleh peneliti. SJK dalam penelitian ini ditambahakan pemanis gula stevia (glikosida steviol). Berdasarkan hasil laporan pengujian laboratorium Saraswati no: SIG.LHP.XI.2013.42496 bahwa setiap $0,3 \mathrm{~g}$ pemanis steviagrow mengandung 95\% glikosida steviol, total lemak $0 \mathrm{~g}$, protein $0 \mathrm{~g}$, dan total karbohidrat $0 \mathrm{~g}$ serta telah terdaftar di Dinas Kesehatan RI P-IRT No: 509331102157318. Selama intervensi, subjek diminta untuk tidak mengonsumsi jus jeruk selain dari yang diberikan serta tidak mengonsumsi suplemen vitamin C.

Data yang dikumpulkan meliputi data karakteristik subjek, konsumsi pangan (recall 2x24 jam dan Food Frequency Quetionnaire (FFQ)), berat dan tinggi badan (pengukuran dengan menggunakan microtoise dan timbangan digital), aktivitas fisik (recall 2x24 jam dan kuesioner), dan sampel darah. Pengumpulan data karakteristik subjek dan aktivitas fisik dilakukan dengan cara wawancara menggunakan alat bantu kuesioner. Pengkategorian IMT yang digunakan berdasarkan batas ambang IMT untuk Asia Tenggara oleh WHO (2000) yakni $\geq 23,0 \mathrm{~kg} / \mathrm{m}^{2}$ (overweight). Tingkat kepatuhan subjek didapatkan dengan cara mengukur sisa konsumsi subjek selama intervensi dilakukan. Pengukuran profil lipid dilakukan diawal sebelum intervensi dan diakhir setelah intervensi SJK.

Analisis profil lipid. Pengumpulan sampel darah subjek diambil melalui pembuluh darah vena sebanyak $5 \mathrm{ml}$ dan dilakukan oleh tenaga medis dari Labkesda Kota Bengkulu. Subjek diminta untuk berpuasa selama 12 jam sebelum dilakukan pengambilan darah. Sampel darah selanjutnya dianalisis di Labkesda Provinsi Bengkulu yang telah terakreditasi oleh Komisi Akreditasi Laboratorium Kesehatan (KALK: 07/S/KALKP/VIII/2012). Uji profil lipid plasma meliputi uji TC, TG, LDL-c dan HDL-c (Analisis profil lipid 
menggunakan metode enzymatic colorimetric test dan diukur dengan spektrofotometer pada panjang gelombang $546 \mathrm{~nm}$.

\section{Pengolahan dan analisis data}

Data diolah menggunakan program SPSS 22.0 for windows dengan signifikansi 5\% $(p<0,05)$. Tingkat kecukupan konsumsi dan kebiasaan konsumsi pangan spesifik pada subjek diolah menggunakan Microsoft Excel 2007 dan mengacu kepada daftar komposisi bahan makanan (DKBM) Indonesia. Karakteristik subjek disajikan secara deskriptif. Uji-t digunakan untuk menguji pengaruh sebelum dan sesudah intervensi SJK.

\section{HASIL DAN PEMBAHASAN}

\section{Karakteristik subjek sebelum intervensi}

Jumlah subjek diawal adalah sebanyak 28 orang, namun terdapat 4 orang subjek yang mengundurkan diri, sehingga total subjek yang mengikuti penelitian ini hingga akhir adalah sebesar 24 orang. Subjek pada penelitian ini berjenis kelamin perempuan. Pemilihan subjek perempuan dikarenakan perempuan memiliki kadar kolesterol yang lebih stabil dibandingkan laki-laki. Selain itu perempuan memiliki hormon estrogen yang membantu menurunkan kadar LDL (Murray et al. 2014).

Berdasarkan hasil independent sample ttest (Tabel 1) menunjukkan bahwa tidak terdapat perbedaan yang nyata pada usia antar subjek pada tiap perlakuan $(\mathrm{p}>0,05)$, dan terdapat pebedaan nyata pada tingkat pendidikan subjek $(\mathrm{p}<0,05)$.

Tabel 1. Karakteristik subjek

\begin{tabular}{|c|c|c|c|}
\hline \multirow{2}{*}{ Variabel } & \multicolumn{2}{|c|}{ Perlakuan } & \multirow[b]{2}{*}{ p } \\
\hline & A & B & \\
\hline Usia & $40,3 \pm 7,1$ & $37,7 \pm 4,9$ & $0,080^{1}$ \\
\hline Status gizi & $25,10 \pm 4,08$ & $25,19 \pm 2,73$ & 0,944 \\
\hline $\begin{array}{l}\text { Tingkat } \\
\text { pendidikan }\end{array}$ & $2,67 \pm 1,03$ & $3,92 \pm 0,28$ & $0,001^{2 a}$ \\
\hline \multicolumn{4}{|c|}{ Riwayat kesehatan keluarga: } \\
\hline $\begin{array}{l}\text { Tinggi } \\
\text { kolesterol }\end{array}$ & $1,92 \pm 0,28$ & $1,83 \pm 0,37$ & $0,234^{2}$ \\
\hline $\begin{array}{l}\text { Diabetes } \\
\text { melitus }\end{array}$ & $1,67 \pm 0,47$ & $1,83 \pm 0,37$ & $0,073^{2}$ \\
\hline Jantung & $1,92 \pm 0,28$ & $2,00 \pm 0,00$ & $0,039^{2 a}$ \\
\hline Hipertensi & $1,58 \pm 0,48$ & $1,67 \pm 0,47$ & $0,444^{2}$ \\
\hline Kanker & $2,00 \pm 0,00$ & $1,83 \pm 0,37$ & $0,001^{2 a}$ \\
\hline Stroke & $1,92 \pm 0,28$ & $1,92 \pm 0,28$ & $1,000^{2}$ \\
\hline
\end{tabular}

Pada perlakuan A rata-rata subjek hanya menyelesaikan pendidikan hingga tingkat Sekolah Menengah Pertama (SMP) sedangkan pada perlakuan B, rata-rata subjek menyelesaikan pendidikan hingga tingkat Sekolah Menengah Atas (SMA) hingga Perguruan Tinggi (PT). Menurut Atmarita \& Fallah (2004), tingkat pendidikan yang tinggi memungkinkan seseorang untuk memperoleh informasi yang luas, khususnya yang terkait dengan kesehatan dan gizi.

Subjek memiliki IMT $\geq 23 \mathrm{~kg} / \mathrm{m}^{2}$. Menurut WHO (2000), nilai IMT $\geq 23 \mathrm{~kg} / \mathrm{m}^{2}$ untuk negara Asia bagian Tenggara memiliki risiko terkena berbagai penyakit kronis. Menurut Sudikno et al. (2015) prevalensi overweight berdasarkan analisis data Riskesdas tahun 2013 pada penduduk usia 25-65 tahun sebanyak $26,1 \%$ dan rata-rata IMT adalah $24,02 \pm 3,70 \mathrm{~kg} / \mathrm{m}^{2}$. Menurut Diana et al. (2013) dengan menganalisis data Riskesdas tahun 2013 juga menunjukkan bahwa sebanyak $29,4 \%$ perempuan dengan rentang usia 19-55 tahun mengalami kegemukan (obes), sedangkan tingkat pendidikan (OR untuk pendidikan lebih tinggi $=0,817 ; 95 \% \mathrm{CI}: 0,782-0,853)$ merupakan faktor protektif kegemukan.

Terdapat perbedaan yang nyata $(p<0,05)$ pada jumlah riwayat kesehatan keluarga, yakni penderita jantung dan kanker. Menurut Brown (2011), obesitas merupakan salah satu faktor risiko pemicu terjadinya peningkatan kolesterol dalam darah. Untuk mengurangi risiko diabetes, penyakit jantung koroner dan kanker, pria dan wanita direkomendasikan untuk mempertahankan berat badan yang ideal dan menghindari kelebihan berat badan, obesitas, serta peningkatan kadar kolesterol diatas normal (Belviranl \& Gokbel 2006; Liu et al. 2000).

\section{Tingkat kepatuhan konsumsi produk inter- vensi}

Tingkat kepatuhan konsumsi masing-masing produk intervensi perlakuan A dan B cukup tinggi, yakni secara berurutan $79,80 \%$ dan 94,07\%. Tingkat persentase kepatuhan konsumsi perlakuan A lebih rendah $(79,80 \%)$ daripada perlakuan B. Hal tersebut dimungkinkan karena rasa asam jeruk kalamansi, dimana perlakuan $\mathrm{A}$ mendapatkan $100 \%$ sari jeruk kalamansi sedangkan perlakuan $\mathrm{B}$ hanya mendapatkan konsentrat sari jeruk kalamansi $50 \%$ dan penambahan $50 \%$ air putih. Namun, hasil independent t-test menyatakan bahwa tidak terdapat perbedaan signifikan pada tingkat kepatuhan konsumsi subjek antar perlakukan $(p=0,092)$. 
Tabel 2. Profil lipid plasma sebelum dan setelah intervensi

\begin{tabular}{|c|c|c|c|c|c|c|c|c|c|}
\hline \multirow{2}{*}{$\begin{array}{l}\text { Profil } \\
\text { lipid } \\
(\mathrm{mg} / \mathrm{dl})\end{array}$} & \multicolumn{2}{|c|}{ Perlakuan A (Rata-rata \pm SD) } & \multirow[b]{2}{*}{$\mathrm{p}^{1^{*}}$} & \multirow{2}{*}{$\operatorname{Selisih}(\Delta)$} & \multicolumn{2}{|c|}{ Perlakuan B(Rata-rata \pm SD) } & \multirow[b]{2}{*}{$\mathrm{p}^{2}$} & \multirow{2}{*}{$\operatorname{Selisih}(\Delta)$} & \multirow{2}{*}{$\mathrm{p}^{3^{*}}$} \\
\hline & Sebelum & Setelah & & & Sebelum & Setelah & & & \\
\hline $\mathrm{TC}$ & $178,00 \pm 17,17$ & $154,50 \pm 23,78$ & 0,028 & $-23,50 \pm 30,90$ & $139,91 \pm 26,48$ & $151,91 \pm 28,04$ & 0,223 & $12,00 \pm 30,80$ & 0,013 \\
\hline TG & $90,33 \pm 23,94$ & $66,66 \pm 20,75$ & 0,004 & $-23,67 \pm 21,81$ & $97,00 \pm 58,39$ & $94,66 \pm 70,02$ & 0,736 & $-2,33 \pm 22,39$ & 0,034 \\
\hline HDL-c & $51,25 \pm 12,68$ & $61,50 \pm 9,49$ & 0,016 & $10,25 \pm 11,91$ & $55,33 \pm 10,83$ & $55,66 \pm 13,26$ & 0,900 & $0,33 \pm 8,57$ & 0,036 \\
\hline LDL-c & $110,33 \pm 18,32$ & $79,75 \pm 23,13$ & 0,002 & $-30,58 \pm 25,05$ & $64,25 \pm 21,27$ & $76,66 \pm 27,28$ & 0,151 & $12,42 \pm 26,66$ & 0,001 \\
\hline
\end{tabular}

$\mathrm{TC}=$ Kolesterol total; ${ }^{*}$ t-test signifikan pada $\mathrm{p}<0,05 ; \mathrm{p}^{1}=\mathrm{p}$ antara sebelum dan setelah intervensi pada kelompok $\mathrm{A} ; \mathrm{p}^{2}=\mathrm{p}$ antara sebelum dan setelah intervensi pada kelompok $\mathrm{B} ; \mathrm{p}^{3}=\mathrm{p}$ antar perlakuan A dan perlakuan B.

\section{Profil lipid subjek setelah intervensi}

Tabel 2 menunjukkan bahwa terdapat penurunan yang signifikan $(\mathrm{p}<0,05)$ pada selisih TC, TG, LDL-c, dan peningkatan HDL-c setelah subjek di intervensi sari jeruk kalamansi (perlakuan A). Produk yang diberikan pada perlakuan A dapat menurunkan TC, TG, LDL-c, dan meningkatkan HDL-c secara signifikan $(\mathrm{p}<0,05)$ dibandingkan produk yang diberikan pada perlakuan B.

Penelitian Mulero et al. (2012), TC signifikan menurun setelah mengonsumsi jus jeruk $300 \mathrm{ml}$ (95\% JC dan 5\% A.melanocarpa ekstrak). Penelitian Tajoda et al. (2013) mengonsumsi jeruk lemon secara signifikan dapat menurunkan kadar total kolesterol sebesar 52\% dan LDL-c. Menurut Kurowska et al. (2000), flavonoid dari buah jeruk, seperti hesperidin dan naringin dapat menurunkan kosentrasi triasilgliserol sebesar $30 \%$, rasio LDL: HDL-c 16\%, dan meningkatkan HDL-c sebesar $21 \%$ pada individu hiperkolesterolemia. Penelitian Li et al. (2013) menyatakan bahwa mengonsumsi pangan tinggi kandungan flavonoid dan flavonol dapat menurunkan konsentrasi serum trigliserida dan rasio TG:HDL secara signifikan $(\mathrm{p}=0,020$ dan $\mathrm{p}=0,040)$ pada perempuan, namun tidak signifikan pada laki-laki dewasa di Cina.

Berdasarkan hasil telaah berbagai pustaka yang telah dilakuan sebelumnya, bahwa terjadi penurunan LDL-c, kolesterol total, TG dan peningkatan HDL secara signifikan setelah diberikan intervensi berbagai jenis jus jeruk. Sejalan dengan hal tersebut, dalam penelitian ini juga memberikan hasil yang sama, dengan hasil signifikan pada pemberian SJK 100\% (perlakuan A).

Penurunan $(\Delta)$ kolesterol total sebanyak $-23,50 \mathrm{mg} / \mathrm{dl}$ atau sebesar $12,34 \%$, TG sebanyak $-23,67 \mathrm{mg} / \mathrm{dl}$ atau $23,64 \%$, LDL sebanyak $-30,58$ $\mathrm{mg} / \mathrm{dl}$ atau $26,90 \%$ dan peningkatan $(\Delta) \mathrm{HDL}$ sebesar $10,25 \mathrm{mg} / \mathrm{dl}$ atau $26,29 \%$ pada wanita dewasa yang kelebihan berat badan. Namun tidak signifikan $(p>0,05)$ pada perlakuan B $(300 \mathrm{ml}$ $50 \%$ SJK). Meskipun demikian, pada perlakuan
$\mathrm{B}$ terdapat kecenderungan penurunan $\mathrm{TG}$ sebesar $6,84 \%$ dan peningkatan HDL sebesar 1,04\%.

Namun hasil yang berbeda ditunjukkan pada penelitian Cesar et al. (2010), dimana penurunan yang signifikan hanya terdapat pada nilai $\Delta$ LDL yakni $-26 \mathrm{mg} / \mathrm{dl}(\mathrm{p}<0,01)$ pada subjek dewasa yang hiperkolesterolemia. Nilai HDL dan TG tidak menunjukkan adanya perbedaan yang signifikan pada kedua perlakuan. Cesar et al. (2010) memberikan $750 \mathrm{ml} \mathrm{(1:6} \mathrm{jus} \mathrm{jeruk} \mathrm{(OJ)/}$ air) dengan kandungan hesperidin $42 \mathrm{mg}$, naringin $12 \mathrm{mg} / 107,14 \mathrm{ml}$ OJ dan vitamin C 258 $\mathrm{mg} / 750 \mathrm{ml}$ OJ. Sama halnya dengan penelitian Demonty et al. (2010) bahwa flavonoid yakni hesperidin (80\%/kapsul) dan naringin (93\%/kapsul) tidak signifikan menurunkan TC, LDL dan juga tidak signifikan meningkatkan HDL-c pada pria dan wanita yang hiperkolesterol (moderat). Hal tersebut dimungkinkan karena jumlah intervensi jus jeruk yang diberikan.

Komponen aktif yang diduga berperan kuat dalam perbaikan profil lipid dalam penelitian ini adalah vitamin $\mathrm{C}$, flavonoid, dan kandungan polifenol buah jeruk kalamansi. Hasil penelitian Bhat et al. (2011), didalam $100 \mathrm{ml} \mathrm{SJK}$ terkandung vitamin C sebesar 40,20 mg. Wang et al. (2008) menyatakan bahwa dalam tiap gram daging buah dan kulit jeruk kalamansi masingmasing mengandung total flavonoid sebesar 8,41 dan $41,00 \mathrm{mg} / \mathrm{g}$, serta terkandung total polifenol sebesar 52,30 mg/g. Menurut Ghafar et al. (2010) Limau kesturi (Citrus microrarpa) mengandung total fenol sebesar $105,00 \pm 3,00 \mathrm{mg} / 100 \mathrm{ml}$, total flavonoid sebesar $8,70 \pm 0,13 \mathrm{mg} / 100 \mathrm{ml}$.

Menurut Ginter et al. (1977), mengonsumsi vitamin $\mathrm{C}$ dosis $0,5-1 \mathrm{~g}$ /hari dapat menurunkan kolesterol total pada subjek hiperlipidemia atau pada subjek yang rendah asupan vitamin C. Menurut Harats et al. (1998) secara in vivo vitamin $\mathrm{C}$ dapat menurunkan oksidasi lipoprotein pada partikel LDL karyawan laki-laki hiperlipidemia. Intervensi suplemen vitamin $\mathrm{C}$ sebanyak $1.000 \mathrm{mg}$ dapat menurunkan TG subjek diabetes melitus tipe II (Ardekani \& Shojaoddiny 2007). 
Sejalan dengan penelitian Mulero et al. (2012), intervensi $300 \mathrm{ml}$ jus jeruk dengan kandungan flavanone sebesar $11,45 \mathrm{~g} / 100 \mathrm{ml}$ jus jeruk, hesperidin sebesar 13,54 g/100 ml jus jeruk, dan flavanons sebesar $0,59 \mathrm{~g} / 100 \mathrm{ml}$ jus jeruk), secara signifikan dapat menurunkan kadar LDL teroksidasi kelompok perlakuan dibandingkan kelompok plasebo. Menurut Jing et al. (2013), kandungan flavonoid yakni d-limonene pada buah jeruk sebanyak $0,6 \mathrm{~g} / \mathrm{bb}$ yang diintervensikan pada tikus obes secara efektif menurunkan serum TG, LDL-c, dan meningkatkan HDL-c. Sehingga d-limonene pada buah jeruk sangat bermanfaat sebagai suplemen untuk mencegah ataupun untuk memperbaiki penyakit dislipidemia ataupun hi-perglikemia pada manusia dan hewan. Gorinstein et al. (2007) memberikan intervensi hesperidin $(0,10 \mathrm{mg} / 1 \mathrm{ml})$ dan naringin $(0,46 \mathrm{mg} / 1 \mathrm{ml})$ yang bersumber dari grapefruit and shamouti (citrus sinensis) pada tikus yang diberi diet tinggi kolesterol. Setelah 30 hari intervensi hasilnya menunjukkan bahwa naringin dan hesperidin meningkatkan aktivitas antioksidan plasma dan secara signifikan menghambat peningkatan plasma lipid pada tikus. Sehingga hesperidin dan naringin pada buah jeruk memiliki potensi antioksidan serta berpotensi tinggi pula dalam penurunan plasma lipid pada tikus yang hiperkolesterolemia.

\section{KESIMPULAN}

Perlakuan A yang mengonsumsi $300 \mathrm{ml}$ sari jeruk kalamansi berpengaruh secara signifikan pada penurunan TC, TG, LDL-c dan meningkatkan HDL-c pada perempuan dewasa yang kelebihan berat badan. Hal ini mengindikasikan bahwa intervensi sari jeruk kalamansi dapat memperbaiki profil lipid subjek. Sehingga diharapkan penelitian selanjutnya untuk meningkatkan tingkat kepatuhan konsumsi subjek dengan cara melakukan pengenceren SJK dengan air minum. Penelitian lanjut diharapkan dapat mengamati efek SJK pada subjek sehat dan juga pada subjek yang mengalami hiperkolesterolemia dan atau hiperlipidemia.

\section{DAFTAR PUSTAKA}

Ardekani MA, Shojaoddiny AA. 2007. Effect of vitamin $\mathrm{C}$ on blood glucose, serum lipids and serum insulin in type 2 diabetes patients. Indian J Med Res 126(5):471-474.

Arabbi PR, Genovese MI, Lajolo FM. 2004. Flavonoids in vegetable foods commonly consumed in Brazil and estimated ingestion by the Brazilian population. J Agric Food Chem 52(5):1124-1131.

Atmarita SF, Fallah T. 2004. Situasi Gizi dan Kesehatan Masyarakat. Widyakarya Nasional Pangan dan Gizi VII. Jakarta.

Belviranl M, Gökbel H. 2006. Acute exercise induced oxidative stress and antioxidant changes. Eur J Gen Med 3(3):126-131.

Bhat R, Nor SBT, Che K, Liong M, Karim. 2011. Sanication Improves Kasturi Lime (Citrus microcarpa) Juice Quality. Ultras. Sonochemistry 18(6): 1295-1300. doi:10.1016/j. ultsonch.2011.04.002.

Boekholdt SM, Meuwese MC, Day NE. 2006. Plasma concentrations of ascor- bic acid and C-reactive protein, and risk of future coronary artery disease, in apparently healthy men and women: the EPIC-Norfolk prospective population study. $\mathrm{Br} \mathrm{J}$ Nutr 96(3):516-522.

Bok SH, Lee SH, Park YB, Bae KH, Son KH, Jeong TS, Choi MS. 1999. Plasma and hepatic cholesterol and hepatic activ- ities of 3-hydroxy-3-methyl-glutaryl-CoA reductase and acyl CoA: cholesterol transferase are lower in rats fed citrus peel extract or a mixture of citrus bioflavonoids. J Nutr 129(6):1181-1185.

Brown JE. 2011. Nutrition Through Life Cycle. USA: Wadsworth.

Cano A, Medina A, Bermejo A. 2008. Bioactive compounds in different citrus varieties. Discrimination among cultivars. J of Food Composition and Analysis 21(5):377-381.

Cesar TB, Aptekmann NP, Milena P. Araujoa, Carmen C. Vinagreb, Raul C. Maranhãob. 2010. Orange juice decreases low-density lipoprotein cholesterol in hypercholesterolemic subjects and improves lipid transfer to high-density lipoprotein in normal and hypercholesterolemic subjects. Nutrition Research 30(10):689-694. doi:10.1016/j. nutres.2010.09.006.

Cooper KH. 2000. Antioxidant revolution. Nashville: Thomas Nelson Publishers.

Demonty I, Lin Y, Zebregs YEMP, Vermeer MA, van der Knaap HCM, Jakel M, Trautwein EA. 2010. The Citrus flavonoids hesperidin and naringin do not affect serum cholesterol in moderately hypercholesterolemic men and women. J Nutr 140(9): 1615-1620.

[Depkes] Departemen Kesehatan 2013. Laporan Hasil Riset Kesehatan Dasar Indonesia Ta- 
hun 2010. Jakarta: Departemen Kesehatan Republik Indonesia.

Diana R, Yuliani I, Yasmin G, Hardinsyah. 2013. Faktor resiko kegemukan pada wanita dewasa indonesia. J Gizi Pangan 8(1):1-8.

Fergusson JJ. 2002. Medicinal Use Of Citrus. Series Of The Holticultural Sciences Departement, Florida Cooperative Extension Service, Institute Of Food And Agriculture Sciences, University Of Florida. 3 pp.

Ghafar MFA, Prasad KN, Weng KK, Ismail A. 2010. Flavonoid, hesperidin, total phenolic contents and antioxidant activities from citrus species. Afr J Biotechnol 9(3):326-330. doi: 10.5897/AJB09.1229.

Ginter E, Cerná O, Budlovský J, Baláz V, Hrubá F, Roch V, Sasko E. 1977. Effect of ascorbic acid on plasma cholesterol in humans in a long-term experiment. Int J Vitam Nutr Res 47(2):123-34.

Gorinstein S, Leontowicz H, Leontowicz M, Krzeminski R, Gralak M, Jastrzebski Z, Park YS, Jung ST, Kang SG, Trakhtenberg S. 2007. Effect of hesperidin and naringin on the plasma lipid profile and plasma antioxidant activity in rats fed a cholesterol-containing diet. J Sci Food Agric. 87(7):1257-1262.

Harats D, Chevion S, Nahir M, Norman Y, Sagee O, Berry EM. 1998. Citurs fruit suplemantation reduce lipoprotein oxidation in young men ingesting a diet high in saturated fat: presumptive evidence for an interaction between vitamins $\mathrm{C}$ and $\mathrm{E}$ in vivo. Am J Clin Nutr 67:245-250.

Jacob R, Hasegawa S, Manners G. 2000. The potential of Citrus limonoids as anticancer agents. Perishables Handing Quartely Issue 102.

Jing L, Zhang Y, Fan S, Gu M, Guan Y, Lu X, Huang C, Zhou Z. 2013. Preventive and ameliorating effects of citrus d-limonene on dyslipedimia and hyperglycemia in mice with high-fat diet-induced obesity. Eur J Pharmacol 715(1):46-55.

Kurowska EM, David SJ, John J, Wetmore S, Freeman DJ, Piché LA, Serratore P. 2000. HDL-C raising effect of orange juice in subjects with hipercholesterolemic. Am J Clin Nutr. 72(5):1095-1100.

Li G, Zhu Y, Zhang Y, Lang J, Chen Y, Ling W. 2013. Estimated daily flavonoid and stilbene intake from fruits, vegetables, and nuts and associations with lipid profiles in Chines adults. Academy of nutrition and dietetics 113(6):2212-2672. doi:10.1016/j. jand.2013.01.018.

[LIPI] Lembaga Ilmu Pengetahuan Indonesia. 2009. Kolesterol. UPT- Balai Informatika Teknologi LIPI. Pangan dan kesehtan.

Liu S, Manson J, Lee IM. 2000. Fruit and vegetable intake and risk of cardiovas- cular disease: the Women's Health Study. Am Jour Clin Nutr 72(4):922-928.

Miyake Y. 2006. Characteristics of flavonoid in niihime fruit-a new sour fruit. Food sci Technol Res 12(3):186-193.

Mulero J, Barnabe J, Cerda B, Viguera CG, Moreno DG, Albaladejo Md, Aviles F, Parra S, Abellah J, Zafrilla P. 2012. Variations on cardiovasculer risk factors in metabolic syndrome after comsume of citrus-based juice. Clinic nutr 31(3):372-377.

Murray RK, Bender DA, Botham KM, Kennelly PJ, Rodwell VW, Weil PA. 2014. Biokimia Harper.

Paulose SM. 2005. Isolation and Effects of Citrus lomonoids on Cytochrome P450 Inhibition, Apoptotic Induction and Cytotoxicity on Human Cancer Cells. Dissertation. Texas and University. $112 \mathrm{pp}$.

Simpson EJ, Brown SJ, Mendis B, Dunlop M, Marshall M, Macdonald A. 2012. The effect of daily orange juice consumption on insulin sensitivity and indices of the metabolic syndrome. Nutr Soc 71 (OCE2), E182. doi :10.1017/S002.

Sudikno, Syarief H, Dwiriani CM, Riyadi H. 2015. Faktor resiko oveweight dan obese pada orang dewasa di Indonesia. Giz Indon 38(2):91-104.

Tajoda HN, Kurian JC, Bredenkamp MB. 2013. Reduction of cholesterol and triglycerides in volunteers using lemon and apple. Int $\mathrm{J}$ Humanit Soc Sci 3:18.

Tripoli E, Guardia M, Giammanco S, Majo D, and Giamanco M. 2007. Citrus flavonoids: molecular structure, biological activity and nutritional properties: a review. Food chem 104(2):466-479.

Wang YC, Chuang Y, Hsu HW. 2008. The flavonoid, carotenoid and pectin content in peels of citrus cultivated in Taiwan. Food chem 106(1):277-284.

Wang YC, Chuang Y, Ku YH. 2007. Quantitation of bioactive compounds in citrus fruits cultivated in Taiwan. Food Chem 102(4):1163-1171.

[WHO] World Health Organization. 2000. The Asia-Pasific Perspective: Redefining Obesity and Its Treatment. WHO Western Or- 
Surlitah dkk.

ganization Pacific Region: IASO International Association for the Study of Obesity. International Obesity Taskforce. ISBN\#09577082-1-1.

[WHO] World Health Organization. 2011. Joint WHO/FAO Expert Consultation on Diet. Nutrition and Prevention of Cronic Diseases. 2002. Geneva. [Online]. http:// www.who.int/world-health-day/q_and_a. en.shtml.
[WHO] World Health Organization. 2010. Global status report on non commnicable diseases. Chronic disease - prevention and control. Chronic disease - epidemiology. Chronic disease - mortality. Cost of illness. Geneva [online] http://www.who.int/nmh/publications/ncd_report_full_en.pdf. 